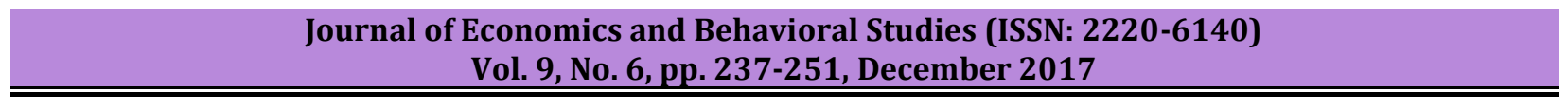

\title{
The Relationship between Oil Price Volatility and Macroeconomic Variables in Nigeria: A Vector Autoregressive (VAR) Approach
}

\author{
Tochukwu Timothy Okoli, Devi Datt Tewari, Ajibola Rhodaoluwafisayomi \\ University of Zululand, South Africa \\ tochukwu.okoli@fuoye.edu.ng, tewariD@unizulu.ac.za,rhophix2014@gmail.com
}

\begin{abstract}
Nigeria as an oil exporting mono-economy is susceptible to fluctuations in the world oil prices. About 97 percent of the government's revenues are gotten from proceeds from oil export. The study attempts to assess the behaviors of macroeconomic variables in the face of oil price volatility in Nigeria. The empirical evidences reveal that macroeconomic variables were susceptibility to volatility in Oil Price. The theoretical framework is based on the Mundel-Flaming model and adopts the variance decomposition and impulse response functions to explain the dynamic properties of the VAR methodology. The impulse response results reveal that a one standard deviation in oil price will trigger a significant change in RGDP, GEXP, INFLATION and IMPORT both in the short and long run, and IR and EXR significantly only in the short run. Finally, the variance decomposition of RGDP, GEXP and EXR reveals that the variability in them were significantly explained by oil price volatility and other tests ran reveals a consistent result. Therefore, volatility in oil price has direct impact on real GDP, Government expenditure, inflation, interest rate, exchange rate and import. The researchers therefore recommend diversification of the economy to other sectors, financial prudence, sound fiscal policy and the lowering of interest rate to stimulate domestic investment.
\end{abstract}

Keywords: Macroeconomics, Growth, Mundell-Fleming Model, Volatility, VAR

\section{Introduction}

Over the decade's oil has remained the main source of revenue to the Nigerian economy. The boom of revenue that the federal government of Nigeria realizes from the oil sector is far more than all the other revenue it gets from other sources of fund put together, hence consisting over ninety seven percent (97\%) of the country's foreign earnings. This invariably has led to the abandonment or better still the death of most of the other sectors of the economy, making the Nigerian economy a mono-economy that is completely dependent on oil. Therefore, any shock or fluctuations in the price of crude oil will virtually affect every facet of the Nigerian economy. Hence, the need to not only study its impact on the economy but to also ensure that the right policy measure is put in place to eradicate or at worse alleviate its negative effect becomes indispensible. The consequential place of oil to the Nigerian economy is well established. Since its discovery in commercial quantities during the years 1973/74, it has grown to assume a pivotal place in the Nigeria economy; constituting the main source of export earnings, foreign exchange and public generated revenue (Obadan, 2014). By the year 1985, the country produced a total of 1.9 million barrels of oil, and that generated a total of N1.78 million as export earnings. By the year 1980, the production of oil rose to 760.1 million barrels and that trickled in a total of N13,306.93 million as export earnings, constituting $96.8 \%$ of total export earnings (CBN, 2012) and ever since then, it has been increasing exponentially. The discovery of oil in Nigeria was in 1958. Before this time, the country's source of foreign earnings is basically agriculture and ironically; relative prices were stable with low/no inflations, unemployment rate was non existing, balance of payment was favorable, and Naira/dollar exchange rate were at per however these became a mirage after the discovery of oil to this time and kept on deteriorating. Hence, the economy is not only susceptible to fluctuations in the oil price but to global macroeconomic shocks.

The price of oil has experienced great fluctuation since the 70s. Philip and Akintoye (2006) observed that it oscillated between $\$ 17$ per barrel and $\$ 26$ at different times in the year 2002 and about $\$ 53$ per barrel by Oct. 2004 and rose to $\$ 60$ by 2005 and Hassan \& Zahid (2011) asserted that during the summer of 2007, the price of one barrel of crude oil jumped to above $\$ 70$ and even crossed $\$ 145$ mark in July 2008. The price staggered between $\$ 61.73$ per barrel in October, 2009 and remained at an average of $\$ 75$ per barrel until August, 2010. It is pertinent to note here that this fluctuation is increasingly getting worse every day and therefore raises serious research interest among scholars especially as oil is the main source of the country's foreign earnings. Oil price variation plays a crucial role in the macroeconomic performance of Nigeria because of its impact on the country's foreign earnings which the annual budgets of the economy hinge. In the light of 
the pivotal place of oil to the Nigeria's economy and the macroeconomic implications of its frequent changes in price, it is pertinent we identify the role and the impact of oil price volatility on the Nigeria's economy as well as proffer solutions to their proper management and stability. This will guide policymakers and economic agents not to expose the economy to further variability. Take for instance, investors will have the confidence to borrow money and invest without any fear of possible capital loss due to changes in interest rate by the monetary authority in trying to mop-up liquidity in order to prevent the Naira exchange rate not to deteriorate. Moreover, foreign direct investment can be discouraged if the global oil price volatility triggers consistent shocks on the macroeconomic indicators within the system. But the question is: how can an economy who is 97 Percent dependent on oil mitigate the effect of changes in its prices? The situation might persist or even gets worse with a positive change in price, therefore this work is aimed at identifying the variables of interest that are highly susceptible to oil price volatility and to what degree as well as identifying a policy measure that can help to cushion these effects by the development of other sectors of the economy.

Statement of the Problem: It is obvious that oil is the mainstay of Nigeria source of revenue and it is the most important driver of the entire economy. Therefore changes in the price of oil have significant effects on economic growth and welfare of the citizenry at large. Take for instance, there have been persistent fluctuations (a fall to be precise) in the price of crude oil in the world oil market in the recent past, with a slow movement in its demand, thereby affecting other macroeconomic aggregates such as a rise in inflation, balance of payment disequilibrium, falling export revenue, deteriorating exchange rate, a rise in interest rate will result in a slowdown productivity as a result of fall in investment as well as a fall in economic growth. With all these and more also being the negative effects of oil price volatility, it makes the prospective future oil supply highly uncertain.

Moreover, it is more likely that in the nearest future, there will be further increasing fluctuations in the oil price. This is because of the uncertainties regarding the discovery of new oil reserves, persistent political instability in Nigeria as well as other exporting countries and worse still the fact that technological improvements have now proffered solutions to other means of crude oil saving devices leading to further fall in the global demand for crude oil, hence a persistent fall in its price. Again, considering the facts that the transmission mechanism through which constant changes in the oil price affects the aggregate economy are enormous, it becomes pertinent to identify these channels for a proper policy mix to counteract its unwanted effects. Take, for instance, an increase in the prices of crude oil is more likely going to increase the costs of production leading to a reduction on output and a rise in prices being passed on to the final consumers. This will further affect other macroeconomic indicators such as high rate of unemployment, high inflation rate, and exchange rate deterioration, fluctuations in the stock market prices, the balance of payment deficits and a general rise in the costs of living. However, the extent to which the shock transmits to the economy is dependent on the structural composition of the economy.

Furthermore, oil price shocks on the international market might be amplified in specific countries, depending on the respective Dollar exchange rate and prevailing inflationary pressures. But for a country like Nigeria that is highly susceptible to changes in the oil price, since oil is the main source of revenue to it, little shock in the oil price will have a quick and touching impact on the economy as a whole therefore, this research really wants to know the behavior of various macroeconomic variables in the face of this oil price shocks as well as the nexus between them. Irrespective of the trade balance of any country of the world, they will still perceive consecutive fluctuations in the oil prices not only uncertain but also detrimental to the entire economic wellbeing, whether they are an oil exporting country or an oil importing country. The Central Bank of Nigeria is interested in the oil price movements in the local and international oil markets because of its direct bearing on Nigeria's annual budget. Majidi (2006) maintains that the bigger the oil-price increase and the longer higher prices are sustained, the bigger the macroeconomic impact. Nigeria became more exposed to oil price fluctuations the moment she started importing refined petroleum products due the collapse of local refineries in the late 1980's (Obioma, 2006). However, the impact of this oil price volatility as argued by Masih et al. (2010) is likely to be significantly greater in oil-importing countries, especially where policy frameworks are weak, foreign exchange reserve is low, and access to international capital markets is limited.

Theoretical Framework: The theoretical model to adopt in this work in order to investigate the interaction between oil price volatility and macroeconomic variables will be the Keynesian open economic model 
(Mundell-Fleming Model). To achieve an internal balance, the fiscal policy instrument of government expenditure is used. This operates through the product market equilibrium by finding the levels of income and interest rate combinations where savings-investment equality takes place so that the product market of the economy is in equilibrium. An increase in government spending will raise the level of income leading to a fall in interest rate and a rise in price level, therefore the product market is in equilibrium when a given level of government spending, relative prices of goods and services, income in the previous years and interest rate interacts to determine the level of income. The Keynesian believes that an expansionary fiscal policy will give rise to an increase in income and rate of interest. The increase in interest rate leads to capital inflow thereby creating short -run balance of payment surplus on capital account and exchange rate appreciation. Whereas the rise in income increase import thereby leading to Balance of payment deficit in current account and exchange rate depreciation. The net overall effect on the balance of payment will depend upon the elasticity of the balance of payment curve.

\section{Literature Review}

Abraham (2015) used quarterly data and adopted the GARCH model as well as a multivariate VAR analysis to investigate the impact of oil price shocks on the Nigerian economy. The impulse response functions show that oil price shocks have immediate and prolonged effect on all the macroeconomic variables considered. He concluded that oil price shocks have a direct impact on real GDP, total monetary assets and credit to private sector and as such urgent and serious efforts should be made to cut back on government expenditure, increase the tax base, diversify the economy and improve the overall efficiency and scope of other existing non-oil revenue sources, so as to ameliorate the impact of falling oil prices. This implies that oil revenue constitutes a greater percentage of the total output in Nigeria. Therefore sufficient attention should be given to it. This result was inconsistent with the findings of Oriakhi \& Iyoha (2010) who found an indirect causality running from oil price volatility to real GDP. Having employed a VAR model to a quarterly data he concluded that oil price changes determine real exchange rate, real import and government expenditure level directly, but indirectly on real GDP, real money supply and inflation through the instrumentality of government expenditure. Therefore, the reverse causality between this two works could be as a result of the periods under consideration and possible structural changes and political changes in the system. Katsuya (2010) in assessing the Impact of Oil Price Volatility on Macroeconomic activity in Russia using the VAR model with a quarterly series spanning from 1994:Q1 to 2009:Q3, giving 63 observations found that the Russian economy is greatly vulnerable to oil price changes. This is because a little change in it triggers reasonable changes on GDP and exchange rate both in the short and long run with a marginal increase in inflation only in the short run. He therefore recommends the needs to diversify by increasing foreign direct investment (FDI) and improve domestic investment.

Wilson et al. (2014) investigated the causal relationship between oil prices and key macroeconomic variables in Nigeria in a multivariate framework using times series data from 1980 to 2010 . He used Granger causality and the ordinary least squares to investigate whether there is prediction between oil prices and macroeconomic indicators (inflation, interest rate, exchange rate and real gross domestic product) and the impact of oil prices on the applied macroeconomic indicators respectively. His findings further stressed that changes in the gross domestic product (GDP) is not influenced by oil price volatility, nor do they find evidence of influence on key macroeconomic variables during the short and long runs with a positive but insignificant relationship between oil price and the Nigerian Gross domestic product. Ogundipe et al. (2014) examined the effects of oil price, external reserves and interest rate on exchange rate volatility in Nigeria using the GARCH and the EGARCH models. He found a long run relationship among the variables with the use of Johansen Cointegration technique while the vector correction mechanism was used to examine the speed of adjustment of the variables from the short run dynamics to the long run equilibrium. It was observed that a proportionate change in oil price leads to a more than proportionate change in exchange rate volatility in Nigeria; which implies that exchange rate is susceptible to changes in oil price. The study recommends that in order to dwindling the impact of crude oil as the mainstay of the economy and overcome the effect of incessant changes in crude oil prices which often culminate into macroeconomic instability the Nigeria government should diversify from the oil sector to other sectors.

Hodo, Akpan and Offiong (2013) employing annual time series data spanning the year (1970-2010) and the methodology of VAR examine the asymmetric effect of oil price shocks on exchange rate volatility and 
domestic investment in Nigeria. The study revealed a consistent result with the findings of Oriakhi \& Iyoha (2010) that government expenditure exhibited a direct and an immediate positive response to oil price shock, but public investment, private investment and industrial production exhibited negative response to oil price shock, further confirming the evidence of a "Dutch disease" in Nigeria. The variance decomposition analysis further revealed that exchange rate, government expenditure and domestic investment are mainly affected by oil price shock, particularly in the short-run. Therefore, this suggests that fiscal policy tool of government expenditure is a potential instrument in ensuring internal and external balances. Englama et al. (2010) in an empirical work designed to examine the oil price-exchange rate nexus, employed monthly data for the period 1999:1 to 2009:12 and utilize the methodology of VECM. The study discovered that both oil price volatility and the demand for foreign exchange impact on exchange rate volatility both in the short-run and the longrun. Essentially, the study discovered that the demand for foreign reserves put more pressure on exchange rate than oil price volatility. Using monthly panel of G7 countries Chen and Chen (2007) investigate the long run relationship between real oil price and real exchange rates and they found that real oil prices is a dominant cause of real exchange rate movements. This could be more true to a country like Nigeria who is more exposed to external shocks due to the country's over dependency on oil as a main source of revenue.

Olomola (2006) investigated the impact of oil price shocks on aggregate economic activity in Nigeria using quarterly data from 1970 to 2003 . He discovered that contrary to previous empirical findings, oil price shocks do not affect output and inflation in Nigeria significantly. However oil price shocks were found to significantly influence the exchange rate. However, this can be justified on the ground that the period the work covered does not really capture the period of sufficient output growth within the economy. Al-Zee (2011) in Bahrain used Johansen co integration test to examine the co integrating relationship between the real GDP, real effect exchange rate and real oil price of a country. Real GDP of Bahrain is more elastic to changes in international oil prices than real exchange rate. Research conducted on Vietnam from the period of 1995 to 2009 using the vector autoregressive model (VAR) produce results that suggest that both oil prices and the real effective exchange rates have strong significant impact on economic activity. Habib and Kalamova (2007) investigate the effect of oil price on the real exchange rate of three countries Norway, Saudi Arabia and Russia. In case of Russia a positive long run relationship was found between oil price and exchange rate and no impact of oil price on exchange rate was found for Norway and Saudi Arabia.

Aliyu (2009) believed that this is caused because of lack on strong institutions and total dependency on oil exports. Aliyu (2009) recommended larger divergence of the economy through the investment in top prolific sector to reduce the adverse effect of oil price shocks and the exchange rate volatility. Oil price has a strong influence on oil dependent countries and their currency is referred to as oil currency whereas for countries like Norway and Canada which are developed and have strong institutions there are weak influences of oil price on exchange rate and economic activities in this countries. Ahuru and James (2015) verified the direct and indirect impact of oil price volatility on Nigeria's economy. The indirect impact attempts to trace the impact of oil price volatility on selected macroeconomic variables through public expenditure, while the direct impacts tied the same selected macroeconomic variables directly on oil price volatility. The methodologies used in the study were VAR, dynamic simulations of forecasting error variance decomposition and the pair wise Granger causality. The study finds out that oil price volatility significantly stimulate most of the macroeconomic variables through the public expenditure. The study recommended that efforts should be made to safeguard both the quantity and quality of public expenditure through appropriate revenue policy measure, promoting sound fiscal institutions, promote budget flexibility and diversification of the revenue base.

\section{Methodology}

The unrestricted Vector Auto Regression (VAR) model will be adopted and interpreted with the standard Choleski decomposition method as well as conduct the Granger causality test procedures. This method is preferred to other methods because it is suitable for addressing structural changes and for testing the long run policy implications.

Model Specification: The Unrestricted VAR model of order one is represented in equation 2; however, due to the peculiarity of Nigerian economy, other factors identified by empirical literatures which describes the 
effect of oil price volatility on growth in Nigeria will be included in the model; hence, adopting Keynesian open economic model as specified by Blanchard, 2008 is as follows:

$Y_{t}=\quad f(I N F, I R$, GEXP, OILPRICE, EXR, IMP $)$

The model is summarized in the reduced-form VAR model as follows:

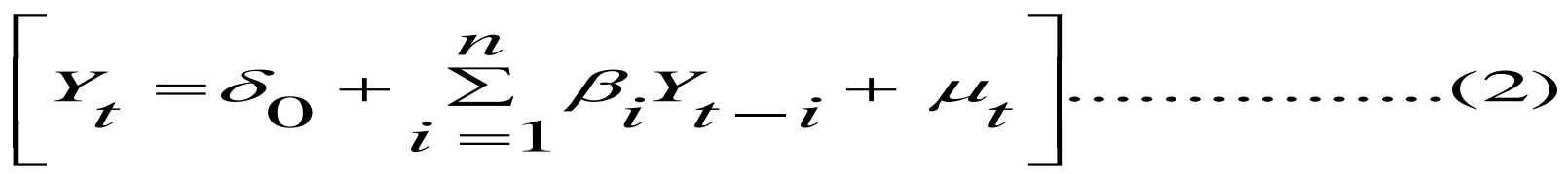

All variables are in normal form. $\beta_{\mathrm{i}}$ are coefficient matrices of size $6 \times 6$ and $\mathrm{u}_{\mathrm{t}}$ is the prediction error, $\delta_{\mathrm{o}}$ is the intercept matrix of $6 * 1$. $\mathrm{Y}_{\mathrm{t}}$ is a $6 * 1$ vector of variables (INF, IR, GEXP, EXR, OILPRICE, IMP)

Where: $\mathrm{Y}_{\mathrm{t}} \quad=$ Real GDP/Output in the current year

$\mathrm{f} \quad=$ Functional notation

INF = Inflation Rate

IR $=$ Interest rate

EXR = Naira/Dollar Nominal Exchange rate (ER) as proxy for import

OILPRICE = Oil Price a proxy for Exports

IMP = Import

GEXP = Government Expenditure

The structural equation for the model is stated as follows:

$O I L P V O L_{t}=\sigma_{0}+\sigma_{1} R G D P_{t-1}+\sigma_{2} I N F_{t-1}+\sigma_{3} I R_{t-1}+\sigma_{4} E X R_{t-1}+\sigma_{5} G E X P_{t-1}+\sigma_{6} I M P_{t-1}$

$I N F_{t}=\lambda_{0}+\lambda_{1} R G D P_{t-1}+\lambda_{2} I M P_{t-1}+\lambda_{3} I R_{t-1}+\lambda_{4} E X R_{t-1}+\lambda_{5} O I L P V O L_{t-1}+\lambda_{6} G E X P_{t-1}$

$I R_{t}=\pi_{0}+\pi_{1} R G D P_{t-1}+\pi_{2} I N F_{t-1}+\pi_{3} I M P_{t-1}+\pi_{4} E X R_{t-1}+\pi_{5} O I L P V O L_{t-1}+\pi_{6} G E X P_{t-1}$

$R G D P_{t}=\alpha_{0}+\alpha_{1} I R_{t-1}+\alpha_{2} I N F_{t-1}+\alpha_{3} E X R_{t-1}+\alpha_{4} I M P_{t-1}+\alpha_{5} O I L P V O L_{t-1}+\alpha_{6} G E X P_{t-1}$

$G E X P_{t}=\varphi_{0}+\varphi_{1} R G D P_{t-1}+\varphi_{2} I N F_{t-1}+\varphi_{3} I R_{t-1}+\varphi_{4} E X R_{t-1}+\varphi_{5} I M P_{t-1}+\varphi_{5} O I L P V O L_{t-1}$

$E X R_{t}=\beta_{0}+\beta_{1} R G D P_{t-1}+\beta_{2} I N F_{t-1}+\beta_{3} I R_{t-1}+\beta_{4} G E X P_{t-1}+\beta_{5} O I L P V O L_{t-1}+\beta_{6} I M P_{t-1}$

$I M P_{t}=\delta_{0}+\delta_{1} R G D P_{t-1}+\delta_{2} I N F_{t-1}+\delta_{3} I R_{t-1}+\delta_{4} G E X P_{t-1}+\delta_{5} O I L P V O L_{t-1}+\delta_{6} E X R_{t-1}$

However, in order to account for the volatility in oil price, the mean deviation of oil price will be estimated to control for its volatility on the economy thus:

$U_{t}=$ OilPrice $_{t^{-}} \alpha_{1}$ OilPrice $_{t-1}-\alpha_{0}$........

Where $U_{t}$ is the Mean Deviation for Oil Price representing the Volatility of Oil Price.

The Granger (short-run) causality approach: Causality in the sense of Granger can be defined by stating that a time series $X$ causes a time series $Y$ if the present value of $Y$ can be better predicted using past values of $\mathrm{X}$ in addition to all other relevant information. Needless to say, the correct estimation procedure would be to include all independent variables indicated by the relevant economic theory. Excluding appropriate variables may yield irrelevant and useless results. Granger considers a system of the general form:

$$
\begin{aligned}
& Y_{t}=\sum_{i=1}^{n} \delta_{i} Y_{t-1}+\sum_{i=1}^{m} \beta_{i} X_{t-1}+\mu_{1 t} \ldots \ldots \ldots \ldots \ldots \ldots \ldots \ldots \ldots \ldots \ldots \ldots \ldots \ldots \ldots \\
& X_{t}=\sum_{i=1}^{\pi} \lambda_{i} Y_{t-1}+\sum_{i=1}^{\kappa} \alpha_{i} X_{t-1}+\mu_{2 t} \ldots \ldots \ldots \ldots \ldots
\end{aligned}
$$

and

Where $\mathrm{X}$ and $\mathrm{Y}$ are stationary series and $\mathrm{u}_{1}$ and $\mathrm{u}_{2}$ are white noise processes. 
Testing the hypothesis that $\mathrm{X}$ does not cause $\mathrm{Y}$ is equivalent to testing the joint restriction that $\beta_{i}=0$ for $\mathrm{i}=$ $1, \ldots, \mathrm{m}$, while testing that $\mathrm{Y}$ does not cause $\mathrm{X}$ implies $\lambda_{i}=0$ for $\mathrm{i}=1, \ldots, \pi$.

Sources and Methods of Data Collection: The data to be used in this study is a secondary quarterly data spanning from the period of 1980 first quarter to 2014 fourth quarter and they are sourced from the central Bank of Nigeria Statistical Bulletin, publication, annual report and statement of account and economic and financial reviewed of various year supplemented with these data from the CBN statistical bulletin (2015). The period covered is essential as it includes the pre SAP and the post SAP periods in Nigeria. Also, it is sufficiently large to capture periods of volatility in the oil price. Structural Adjustment Program is a period in Nigeria when government embarked on serious structural programs that had a far reaching implication for the macroeconomic environment in Nigeria.

\section{Results and Analysis}

This section of the research work covers the presentation of the empirical results as well as the analysis and discussion of the results. The analysis begins with the descriptive statistics of the variables to the correlation matrix and then to exploration of time series properties of the variables used in the model through test for stationarity, Granger Causality test and then to Cointegration test and finally to Impulse Response test and Variance Decomposition.

Table 1: Descriptive statistics

\begin{tabular}{llllllll}
\hline & RGDP & INF & IR & GEXP & OILPVOL & EXR & IMP \\
\hline Mean & 94083.65 & 19.74193 & 6.012019 & 1279001. & 18.63504 & 65.92612 & 2116419. \\
Median & 25064.40 & 12.68726 & 6.630339 & 428215.2 & 7.330213 & 21.99698 & 529115.3 \\
Maximum & 522963.9 & 76.42606 & 11.83820 & 5185318. & 103.1569 & 159.3309 & 6567883 \\
Minimum & 681.5138 & 0.666756 & 0.144740 & 9636.500 & -12.20526 & 0.516864 & 4567.700 \\
Std. Dev. & 147040.0 & 18.04813 & 2.878867 & 1651571. & 29.79784 & 63.14380 & 6010518. \\
Skewness & 1.748702 & 1.599351 & -0.325645 & 1.193152 & 1.328678 & 0.269719 & 8.650076 \\
Kurtosis & 4.697235 & 4.379949 & 2.289990 & 2.967729 & 3.548455 & 1.268533 & 90.78481 \\
Jarque-Bera & 88.15588 & 70.79307 & 5.415034 & 33.22370 & 42.94698 & 19.18567 & 46698.57 \\
Probability & 0.000000 & 0.000000 & 0.066702 & 0.000000 & 0.000000 & 0.000068 & 0.000000 \\
Sum & 13171711 & 2763.870 & 841.6826 & $1.79 \mathrm{E}+08$ & 2608.905 & 9229.657 & $2.96 \mathrm{E}+08$ \\
Sum Sq. Dev. & $3.01 \mathrm{E}+12$ & 45277.17 & 1152.014 & $3.79 \mathrm{E}+14$ & 123419.6 & 554212.4 & $5.02 \mathrm{E}+15$ \\
Observations & 140 & 140 & 140 & 140 & 140 & 140 & 140 \\
\hline
\end{tabular}

Authors' Computation

Discussion of Findings: Table 1 above shows the descriptive result for the variables, which include RGDP, INF, IR, GEXP, OILPVOL, EXR and IMP. The result indicates that all the variables under consideration have positive mean with 140 observations. The highest standard deviation was recorded by Government Expenditure of 1651571 while the least standard deviation of 2.878867 is recorded by Interest Rate. The results indicate that the skewness coefficient of the variable interest rate $(-0.325645)$ is less than zero whereas the skewness coefficients of the rest of the variables which includes RGDP, INF, GEXP, OILPVOL, EXR and IMP are all greater than zero. The kurtosis coefficients of variables RGDP (4.697235), INF (4.379949), IR (2.289990), IMP (90.78481) GEXP (2.967729) and OILPVOL (3.548455) are all leptokurtic while the kurtosis coefficient of the variable EXR (1.268533) is platykurtic. The estimation above indicates that the Jarque-Bera probability for the variables shows that the error terms are normally distributed. 
Table 2: The Correlation Matrix

\begin{tabular}{llllllll}
\hline & RGDP & INF & IR & GEXP & OILPVOL & EXR & IMP \\
\hline RGDP & 1.000000 & -0.293195 & 0.460811 & 0.959889 & 0.892789 & 0.773486 & 0.408683 \\
INF & -0.293195 & 1.000000 & 0.059343 & -0.337858 & -0.355214 & -0.365342 & -0.131572 \\
IR & 0.460811 & 0.059343 & 1.000000 & 0.476877 & 0.346594 & 0.567190 & 0.313217 \\
GEXP & 0.959889 & -0.337858 & 0.476877 & 1.000000 & 0.902610 & 0.870071 & 0.442440 \\
OILPVOL & 0.892789 & -0.355214 & 0.346594 & 0.902610 & 1.000000 & 0.739990 & 0.433233 \\
EXR & 0.773486 & -0.365342 & 0.567190 & 0.870071 & 0.739990 & 1.000000 & 0.395388 \\
IMP & 0.408683 & -0.131572 & 0.313217 & 0.442440 & 0.433233 & 0.395388 & 1.000000 \\
\hline
\end{tabular}

Authors' Computation

The Correlation Analysis: The result of the Correlation Matrix as shown above depicts strong positive relationships among Oil Price Volatility and almost all the macroeconomic variables in the model such as Real Gross Domestic Product (RGDP), Real Naira/Dollar Exchange Rate (EXR), Government Expenditure (GEXP), and Interest Rate (IR) although, the relationship between interest rate and Oil Price Volatility is less than $50 \%$ (i.e. 0.346594), yet it is still positive meaning that a rise in Oil Price Volatility will cause a rise in interest rate. The highest of the correlation exists between Oil Price Volatility and Government Expenditure which is more than 90\%. This is consistent with economic apriorial expectation: when changes in the world oil price become increasingly volatile (say steady fall), government expenditure will tend to be more than its revenue leading to deficit financing. The Correlation Matrix also shows a high positive relationship with real GDP, this could be as a result of increase in government expenditure which in turn will have a high multiplier effect on National Income. However, a negative correlation exists between Oil Price Volatility and inflation. This implies that Volatility in Oil Price will tend to reduce inflation rate. Other variables shows a reasonable level of relationship among themselves with the exception of inflation rate which depicts a very low and negative correlation across most of the other variables.

Unit Root Test: To test for stationarity or the absence of unit roots will be carried out using the Augmented Dickey Fuller test (ADF) and Phillips Perron tests, hence the hypothesis is stated as follows: If the absolute value of the Augmented Dickey Fuller (ADF) test is greater than the critical value either at the 1\%, 5\%, or $10 \%$ level of significance or/and if the probability value is less than $5 \%$, then the variables are stationary either at order zero, one ,or two. The Augmented Dickey Fuller test equation is specified below as follows:

$\Delta \widehat{u}_{t}=\beta \widehat{u}_{t-1}+\sum_{i=1}^{k} \Delta \widehat{u}_{t-1}+\varepsilon_{t}$

Table 3: Results of the Augmented Dickey Fuller (ADF) and Philip Perron stationarity test VARIABLES ADF PP

\begin{tabular}{|c|c|c|c|c|c|c|}
\hline & $\begin{array}{l}\text { TEST } \\
\text { STATISTICS }\end{array}$ & $\begin{array}{l}\text { ORDER OF } \\
\text { INTEGRATION }\end{array}$ & PROB. & $\begin{array}{l}\text { TEST } \\
\text { STATISTICS }\end{array}$ & $1^{\text {st }}$ DIFF. & PROB. \\
\hline Oil Price & -7.389594 & $\mathrm{I}(1)$ & 0.0000 & -7.322269 & $\mathrm{I}(1)$ & 0.0000 \\
\hline $\begin{array}{l}\text { Real GDP } \\
\text { Interest Rate }\end{array}$ & $\begin{array}{l}-5.979718 \\
-6.047995\end{array}$ & $\begin{array}{l}\mathrm{I}(1) \\
\mathrm{I}(1)\end{array}$ & $\begin{array}{l}0.0000 \\
0.0000\end{array}$ & $\begin{array}{l}-6.490094 \\
-5.380081\end{array}$ & $\begin{array}{l}\mathrm{I}(1) \\
\mathrm{I}(1)\end{array}$ & $\begin{array}{l}0.0000 \\
0.0000\end{array}$ \\
\hline $\begin{array}{l}\text { Exchange Rate } \\
\text { Inflation Rate } \\
\text { Oil Price Vol. }\end{array}$ & $\begin{array}{l}-6.371757 \\
-3.513339 \\
-7.389594\end{array}$ & $\begin{array}{l}\mathrm{I}(1) \\
\mathrm{I}(0) \\
\mathrm{I}(1)\end{array}$ & $\begin{array}{l}0.0000 \\
0.0090 \\
0.0000\end{array}$ & $\begin{array}{l}-5.923206 \\
-5.665009 \\
-7.322269\end{array}$ & $\begin{array}{l}\mathrm{I}(1) \\
\mathrm{I}(1) \\
\mathrm{I}(1)\end{array}$ & $\begin{array}{l}0.0000 \\
0.0000 \\
0.0000\end{array}$ \\
\hline IMP & -9.468824 & $\mathrm{I}(0)$ & 0.0000 & -9.926330 & $\mathrm{I}(0)$ & 0.0000 \\
\hline GEXP & -12.26873 & $\mathrm{I}(1)$ & 0.0000 & -12.27637 & $\mathrm{I}(1)$ & 0.0000 \\
\hline
\end{tabular}

Authors' Computation 
The result of the augmented Dickey fuller $\{\mathrm{ADF}\}$ unit root test is presented above. From the result, all of the variables are stationary at first difference apart from inflation and import that was stationary at level. We therefore proceed to testing for Cointegration to ascertain whether the variables have a long run relationship. The idea behind cointegration is that even if some variables are not stationary their linear combination may be stationary after all. The existence of cointegration confirms co-movement among the variables and consequently long run relationship exists among the variables. We therefore proceed to conduct the cointegration test.

Causality Test: We utilized the causality test procedure developed by Granger (1969). The result of the causality tests obtained is as follows:

Table 4: Pairwise Granger Causality Tests

\begin{tabular}{|c|c|c|c|}
\hline $\begin{array}{l}\text { Pairwise Granger Causality Tests } \\
\text { Lags: } 2 \\
\text { Null Hypothesis: }\end{array}$ & Obs & F-Statistic & Prob. \\
\hline OILPVOL does not Granger Cause RGDP & & 6.26695 & 0.0025 \\
\hline $\begin{array}{l}\text { RGDP does not Granger Cause OILPVOL } \\
\text { OILPVOL does not Granger Cause INF }\end{array}$ & 138 & $\begin{array}{l}6.04819 \\
0.99567\end{array}$ & $\begin{array}{l}0.0031 \\
0.3722\end{array}$ \\
\hline $\begin{array}{l}\text { INF does not Granger Cause OILPVOL } \\
\text { OILPVOL does not Granger Cause IR }\end{array}$ & 138 & $\begin{array}{l}0.02612 \\
0.28218\end{array}$ & $\begin{array}{l}0.9742 \\
0.7546\end{array}$ \\
\hline $\begin{array}{l}\text { IR does not Granger Cause OILPVOL } \\
\text { OILPVOL does not Granger Cause GEXP }\end{array}$ & 138 & $\begin{array}{l}0.15834 \\
1.39666\end{array}$ & $\begin{array}{l}0.8537 \\
0.2510\end{array}$ \\
\hline $\begin{array}{l}\text { GEXP does not Granger Cause OILPVOL } \\
\text { EXR does not Granger Cause OILPVOL }\end{array}$ & 138 & 10.2134 & 7.E-05 \\
\hline $\begin{array}{l}\text { OILPVOL does not Granger Cause EXR } \\
\text { IMP does not Granger Cause OILPVOL }\end{array}$ & 138 & $\begin{array}{l}3.40057 \\
3.79726\end{array}$ & $\begin{array}{l}0.0363 \\
0.0249\end{array}$ \\
\hline OILPVOL does not Granger Cause IMP & 138 & 5.24585 & 0.0064 \\
\hline
\end{tabular}

Authors' Computation

The Granger causality test is used to show the short run relationship of the nexus between OIL PRICE VOLATILITY and Macroeconomic variables. From the result of the test presented in the table above, it is evident that there is bi-directional causality running between the Real Gross Domestic Product and Oil Price Volatility because the probability value of its F-Statistics are less than 5\%. Though (Rolle \& Uffie, 2015) found a unidirectional causality running from oil price volatility to RGDPGR, both stresses the fact that oil price volatility causes growth. Oil Price Volatility granger causes Import and Import also granger causes Oil Price Volatility, therefore there is also a bi-directional causality existing between Oil Price Volatility and Import; a uni-directional causality exists between Exchange rate and Oil Price Volatility whereas there is no causal relationship between Oil Price Volatility and Inflation rate. The result of the Granger Causality test above depicts that Oil Price Volatility and Real Gross Domestic Product causes each other thereby justifying the assertions made above under the cointegration test that the variables have a long run relationship.

VAR Models: In order to analyze the dynamic properties of the VAR models, the variance decomposition and impulse response functions will be used. The table below displays the impulse responses of the RGDP,INF, IR, GEXP, OILPVOL, EXR, and IMPORT. The X-axis shows the time while the Y-axis shows the percentage variation in the dependent variable away from its base line level. The bold line in each graph is the estimated response while the dashed lines denote the one standard error confidence band around the estimate. There is no consensus on an explicit criterion for significance in a VAR framework. Sims (1987) however suggests that for impulse responses, significance can be crudely gauged by the how much the function moves away from zero, whilst Runkle (1987) suggests a probability range above 10 percent for variance decompositions. 


\section{Figure 1: Impulse response function}
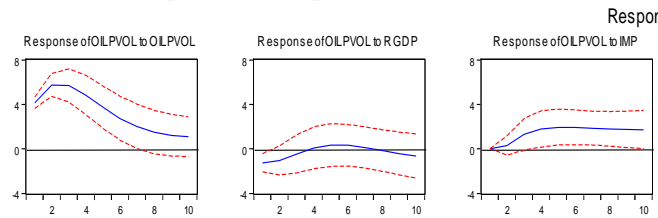

Response to Cholesky One S.D. Innovations \pm 2 S.E.
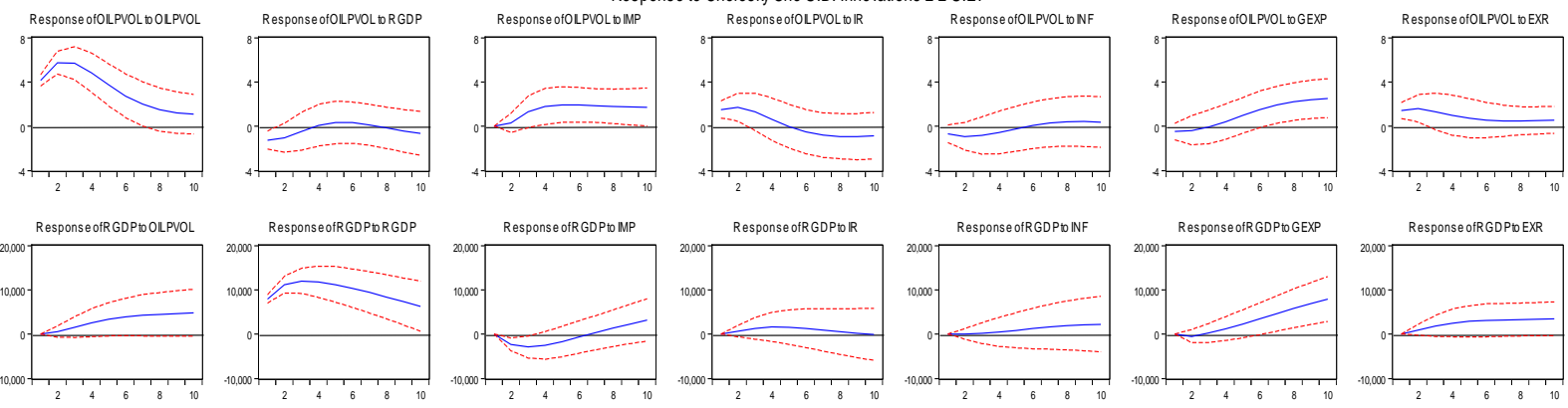

Response ofRGDPto $\mathbb{R}$
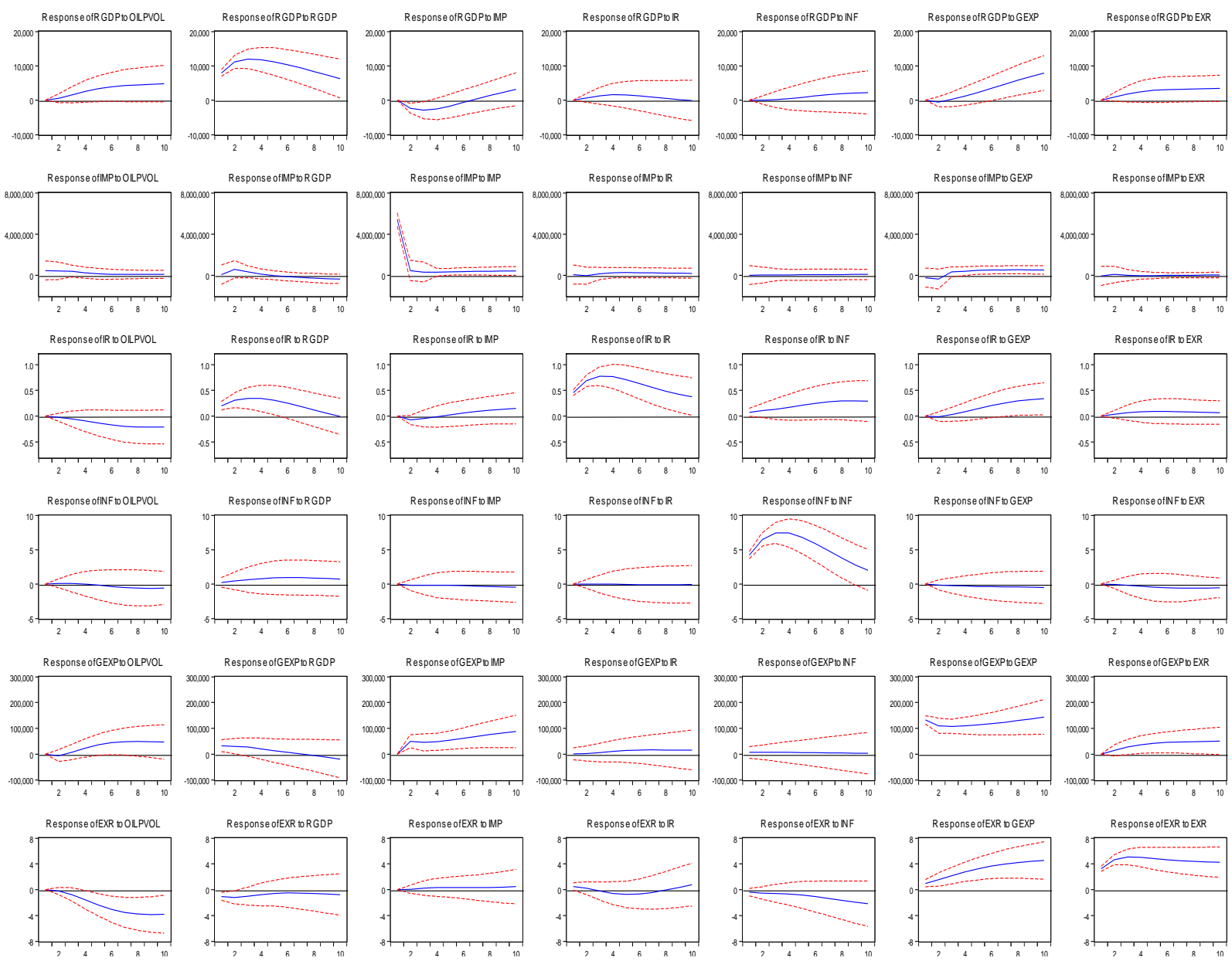

The impulse response graph above shows the response of macroeconomic variables to one standard deviation shock of OILPVOL on the first column while the response on OILPVOL to one standard deviation shock of macroeconomic variables is shown on the first row. Since our interest is to find out the impact of OILPVOL on macroeconomic variables, we proceed to interpret only the first column of our impulse response function. The response of OILPVOL to one standard deviation to its own shock shows a positive but a fluctuating trend into the future and then stabilizes along the horizon; it then becomes relatively stable up to the tenth period but never becomes negative. The response of RGDP to one standard deviation in OILPVOL indicates a positive and a rising response through-out the horizon. This suggests that one standard innovation to OILPVOL will generate an increase in the real gross domestic product within the economy. The impulse response of IMP to one standard innovation in the OILPVOL maintains a stable and a flat response all through the horizon. It neither rises nor falls along the horizon. The impulse response of IR to one standard deviation in OILPVOL is negative and fluctuates further into negative both in the short and long run. The response of INF to one standard innovation in OILPVOL is almost zero in the short run, this is because it lied on the origin up to the fifth quarter and afterwards declines slightly into negative through-out the horizon into the long run. This shows that inflation does not respond much to changes in OILPVOL. A response of GEXP to OILPVOL shock indicates a negative response in the short run but rises into positive in the long run and rises all through the horizon. This shows that a change in the OILPVOL growth rate will trigger a 
significant rise in GEXP. The impulse response function of the EXR to one standard innovation in OILPVOL shock indicates a negative and a fluctuating trend further into negative from the short to the long run.

Variance decomposition: The variance decomposition provides complementary information on the dynamic behavior of the variables in the system. It provides information on the importance of various structural shocks explaining the forecast error variability of OILPVOL that could be attributable to other variables. The tables below show the variance decomposition for each of the variables over the short term period (1-5 years) and over the long term (6-10 years):

Table 5: Variance Decomposition of OILPVOL

\begin{tabular}{lllllllll}
\hline Period & S.E. & OILPVOL & RGDP & IR & INF & IMP & GEXP & EXR \\
\hline 1 & 3.604725 & 71.97409 & 6.658256 & 6.893848 & 0.757305 & 0.530816 & 1.041156 & 12.14453 \\
2 & 6.238187 & 76.86244 & 4.143269 & 5.878215 & 0.917074 & 1.181895 & 0.650662 & 10.36644 \\
3 & 8.446539 & 78.18476 & 2.795720 & 4.812510 & 0.958312 & 3.827919 & 0.415144 & 9.005633 \\
4 & 10.39536 & 77.80939 & 2.195484 & 3.930204 & 0.902483 & 6.672879 & 0.437086 & 8.052474 \\
5 & 12.22377 & 76.20470 & 1.985881 & 3.437452 & 0.809792 & 9.189771 & 0.991743 & 7.380667 \\
6 & 13.99118 & 73.66295 & 1.875632 & 3.358329 & 0.742516 & 11.21270 & 2.268334 & 6.879536 \\
7 & 15.70467 & 70.51196 & 1.756007 & 3.569659 & 0.726846 & 12.74552 & 4.220635 & 6.469369 \\
8 & 17.35483 & 67.09483 & 1.659063 & 3.894478 & 0.746218 & 13.88211 & 6.611535 & 6.111763 \\
9 & 18.93520 & 63.68631 & 1.648863 & 4.190658 & 0.766809 & 14.74679 & 9.161660 & 5.798910 \\
10 & 20.44672 & 60.45137 & 1.754421 & 4.385545 & 0.765507 & 15.44799 & 11.65897 & 5.536203 \\
\hline
\end{tabular}

Authors' Computation

From the table above, we can see that the variance decomposition of the OILPVOL to itself indicates that it accounts for the most of the variability over the periods, ranging between $71 \%$ in the short run to $60 \%$ in the long run. However, RGDP and EXR show that some of the variability or the shock in OILPVOL could be attributed to them, though they show a decreasing pattern from the first quarter; it ranges from $6 \%$ to $1 \%$ and from $12 \%$ to $5 \%$ in the tenth period respectively. Whereas that of IMP shows an increasing pattern ranging from $1 \%$ to $15 \%$ in the tenth period. The shock of the OILPVOL to other variables in the model such as GEXP, INF and IR show a decreasing pattern from 1st quarter with a range from $11 \%, 0.7 \%$ and $4 \%$ respectively in the tenth period. The variance decomposition of RGDP shocks to itself account for the most of the variability over all the periods ranging from $100 \%$ to $68 \%$ in the long run; whereas the shock to OILPVOL ranges from $0 \%$ in the first period to $8 \%$ in the $10^{\text {th }}$ period. This result is consistent with the findings of Verheyen (2010) studying about the US economy attests to the fact that GDP dominates its own shock and that all other shocks account each for about $10 \%$ of the variance. In our study, the result indicates that EXR account for about $4 \%$ of the variance. However, a variance decomposition of RGDP shock to IR, GEXP, IMP, and INF shows different pattern with GEXP accounting for the highest variability among them of about $13 \%$.

Table6: Variance Decomposition of RGDP

\begin{tabular}{lllllllll}
\hline Period & S.E. & OILPVOL & RGDP & IR & INF & IMP & GEXP & EXR \\
\hline $\mathbf{1}$ & 4.865311 & 0.000000 & 100.0000 & 0.000000 & 0.000000 & 0.000000 & 0.000000 & 0.000000 \\
$\mathbf{2}$ & 8.017857 & 0.284771 & 96.32789 & 0.116576 & 0.015252 & 2.594699 & 0.125720 & 0.535096 \\
$\mathbf{3}$ & 10.13264 & 1.101559 & 93.43182 & 0.344004 & 0.060275 & 3.588461 & 0.092303 & 1.381578 \\
$\mathbf{4}$ & 11.44571 & 2.230960 & 90.98402 & 0.516910 & 0.154163 & 3.493497 & 0.360530 & 2.259924 \\
$\mathbf{5}$ & 12.26209 & 3.491011 & 88.52154 & 0.579419 & 0.312217 & 2.974560 & 1.093143 & 3.028105 \\
$\mathbf{6}$ & 12.82565 & 4.729161 & 85.68440 & 0.553504 & 0.536855 & 2.453875 & 2.402379 & 3.639828 \\
$\mathbf{7}$ & 13.28719 & 5.852481 & 82.24905 & 0.488594 & 0.812061 & 2.147986 & 4.348551 & 4.101277 \\
$\mathbf{8}$ & 13.71794 & 6.819959 & 78.13825 & 0.426240 & 1.105755 & 2.149426 & 6.920453 & 4.439912 \\
$\mathbf{9}$ & 14.14211 & 7.623572 & 73.40704 & 0.387525 & 1.378866 & 2.481183 & 10.03504 & 4.686777 \\
$\mathbf{1 0}$ & 14.56425 & 8.270680 & 68.20734 & 0.375294 & 1.596682 & 3.126495 & 13.55438 & 4.869121 \\
\hline
\end{tabular}

Authors' Computation 
Table 7: Variance Decomposition of GEXP

\begin{tabular}{lllllllll}
\hline Period & S.E. & OILPVOL & RGDP & IR & INF & IMP & GEXP & EXR \\
\hline 1 & 7942.340 & 0.000000 & 5.769663 & 0.000000 & 0.000000 & 0.000000 & 94.23034 & 0.000000 \\
2 & 13962.33 & 0.320611 & 5.820819 & 0.000873 & 0.027066 & 6.872731 & 86.42174 & 0.536157 \\
3 & 18842.30 & 0.243915 & 5.502334 & 0.001941 & 0.073424 & 9.014201 & 83.32279 & 1.841396 \\
4 & 22748.17 & 0.730486 & 4.720004 & 0.025398 & 0.112788 & 10.44820 & 80.55533 & 3.407795 \\
5 & 25937.86 & 1.720399 & 3.865665 & 0.068554 & 0.134821 & 11.87364 & 77.53995 & 4.796969 \\
6 & 28634.31 & 2.789924 & 3.119695 & 0.109107 & 0.141232 & 13.38532 & 74.62788 & 5.826841 \\
7 & 31011.63 & 3.633432 & 2.533652 & 0.134192 & 0.137507 & 14.89613 & 72.15497 & 6.510116 \\
8 & 33202.68 & 4.153621 & 2.111886 & 0.143959 & 0.128101 & 16.30882 & 70.22389 & 6.929723 \\
9 & 35307.98 & 4.381911 & 1.849987 & 0.143926 & 0.115770 & 17.56359 & 68.77369 & 7.171124 \\
10 & 37402.45 & 4.395048 & 1.743031 & 0.139547 & 0.102240 & 18.63842 & 67.68095 & 7.300772 \\
\hline
\end{tabular}

Authors' Computation

The major source of variation in GEXP forecast errors shows it is its own shock which ranges from $94 \%$ to $67 \%$ in the long run. The innovations of GEXP to EXR and OILPVOL account for the forecast error variance ranging from $0 \%$ to $7 \%$ and $0 \%$ to $4 \%$ respectively. Hence, we can conclude that government expenditure dose not respond much to variations in the Exchange rate and Oil Price Volatility in the short run but can in the long run as well as to IMP which accounts to about $18 \%$ of the variability in the GEXP. This is further strengthened by the assertion that public expenditure impacts on most of the macroeconomic variables (Rolle and Uffie, 2015). However, the variance decompositions indicate that GEXP shocks explains though not dominant proportion of the forecast error variance of Income (RGDP) in the short run but not in the long run. Moreover, this result shows that INF and IR do not in any way account for the variations in GEXP both in the short and long run.

Table8: Variance Decomposition of EXR

\begin{tabular}{lllllllll}
\hline Period & S.E. & OILPVOL & RGDP & IR & INF & IMP & GEXP & EXR \\
\hline 1 & 0.502954 & 0.000000 & 8.399026 & 0.000000 & 0.000000 & 0.000000 & 7.228794 & 84.37218 \\
2 & 0.915992 & 0.109772 & 6.600038 & 0.605036 & 0.001286 & 0.002708 & 8.468869 & 84.21229 \\
3 & 1.259558 & 0.921435 & 5.049589 & 1.727144 & 0.001036 & 0.039773 & 11.02701 & 81.23401 \\
4 & 1.530797 & 2.946371 & 3.858013 & 2.835740 & 0.019091 & 0.065000 & 13.98584 & 76.28995 \\
5 & 1.742160 & 5.996138 & 3.005758 & 3.523025 & 0.097473 & 0.063599 & 16.90378 & 70.41023 \\
6 & 1.909367 & 9.403472 & 2.419950 & 3.684565 & 0.278725 & 0.051585 & 19.48625 & 64.67545 \\
7 & 2.045994 & 12.53058 & 2.028270 & 3.449752 & 0.584435 & 0.041029 & 21.63465 & 59.73128 \\
8 & 2.161627 & 15.02771 & 1.775134 & 3.021442 & 1.007029 & 0.033598 & 23.37490 & 55.76019 \\
9 & 2.262225 & 16.81320 & 1.619284 & 2.571387 & 1.513228 & 0.028743 & 24.78322 & 52.67094 \\
10 & 2.351288 & 17.96168 & 1.530397 & 2.207139 & 2.054033 & 0.029325 & 25.94491 & 50.27252 \\
\hline
\end{tabular}

Authors' Computation

From the result of the variance decomposition of the EXR obtained, own shock constituted the predominant source of variations for variables in the model. Apart from own shock, the most dominant variable is GEXP and OILPVOL. All through the ten-period horizon, it maintained an average significant influence of $7 \%$ to $25 \%$ and $0 \%$ to $17 \%$ from the short to long run. Other variables could account to an insignificant influence to the changes in EXR throughout the ten periods.

Table 9: Variance Decomposition of INF

\begin{tabular}{lllllllll}
\hline Period & S.E. & OILPVOL & RGDP & IR & INF & IMP & GEXP & EXR \\
\hline 1 & 4.211266 & 0.000000 & 0.366844 & 0.000000 & 97.53329 & 0.000000 & 0.246462 & 1.853400 \\
2 & 7.768606 & 0.020354 & 0.445991 & 0.001507 & 97.33151 & 0.046390 & 0.135558 & 2.018691 \\
3 & 10.77730 & 0.026061 & 0.574002 & 0.003319 & 96.98448 & 0.048553 & 0.091987 & 2.271603 \\
4 & 13.11750 & 0.018384 & 0.750788 & 0.003720 & 96.54526 & 0.048692 & 0.066069 & 2.567086 \\
5 & 14.82444 & 0.022377 & 0.959387 & 0.003375 & 96.03090 & 0.055274 & 0.051743 & 2.876948 \\
6 & 16.00106 & 0.057938 & 1.178376 & 0.002973 & 95.46401 & 0.072669 & 0.046417 & 3.177620 \\
7 & 16.76973 & 0.128984 & 1.388801 & 0.002723 & 94.87372 & 0.104689 & 0.050204 & 3.450882 \\
8 & 17.24631 & 0.224017 & 1.577986 & 0.002637 & 94.29165 & 0.153381 & 0.065372 & 3.684957 \\
\hline
\end{tabular}




\begin{tabular}{lllllllll}
\hline 9 & 17.52781 & 0.323770 & 1.740239 & 0.002877 & 93.74475 & 0.217879 & 0.095654 & 3.874827 \\
10 & 17.68822 & 0.410372 & 1.875411 & 0.003807 & 93.24933 & 0.294542 & 0.145140 & 4.021401 \\
\hline
\end{tabular}

Authors' Computation

The result from the table above shows that the variance decomposition of the INF to itself indicates that it accounts for the most of the variability over all periods; it ranges from $97 \%$ in the short run to $93 \%$ in the long run. This means that inflation account for almost all the variations in itself both in the short and long run. The shock of INF to rest of the variables reveals that they all had an insignificant impact in explaining the variability in INF both in the short and long run. However, EXR explained to the tune of $4 \%$ only in the long run.

Table 10: Variance Decomposition of IR

\begin{tabular}{lllllllll}
\hline Period & S.E. & OILPVOL & RGDP & IR & INF & IMP & GEXP & EXR \\
\hline 1 & 5447982. & 0.000000 & 15.92974 & 79.98212 & 2.722580 & 0.000000 & 0.021540 & 1.344019 \\
2 & 5529038. & 0.032419 & 16.21314 & 78.13057 & 2.689561 & 0.697305 & 0.006525 & 2.230482 \\
3 & 5576653. & 0.163498 & 16.17912 & 77.15292 & 2.998434 & 0.533606 & 0.131833 & 2.840585 \\
4 & 5612407. & 0.464111 & 15.96850 & 75.81959 & 3.623807 & 0.374933 & 0.517400 & 3.231651 \\
5 & 5653162. & 0.960978 & 15.45847 & 74.03690 & 4.535421 & 0.297227 & 1.276787 & 3.434218 \\
6 & 5698433. & 1.631982 & 14.63432 & 71.84423 & 5.664270 & 0.303578 & 2.426744 & 3.494869 \\
7 & 5747600. & 2.403798 & 13.59190 & 69.35926 & 6.893802 & 0.386941 & 3.902170 & 3.462132 \\
8 & 5799587. & 3.183046 & 12.48294 & 66.74775 & 8.086871 & 0.539485 & 5.581816 & 3.378096 \\
9 & 5853365. & 3.890908 & 11.45296 & 64.17234 & 9.123737 & 0.753340 & 7.332925 & 3.273797 \\
10 & 5907966. & 4.482092 & 10.60267 & 61.75267 & 9.928379 & 1.020217 & 9.045066 & 3.168906 \\
\hline
\end{tabular}

Authors' Computation

The variance decomposition of the IR shows that among all the variables, its own shock explains about 79\% to $61 \%$ of the forecast error variance during the period under review. However, the result shows that RGDP explains a reasonable percentage of the variations in interest rate of about $15 \%$ and $10 \%$ of the variation. Also the result indicates that apart from RGDP, INF explains about $9 \%$ of the changes in the IR, while OILPVOL explain about $4 \%$ of the changes in the IR. The variance decomposition of IR to GEXP, EXR and IMP explains about $9 \%, 3.1 \%$ and $1 \%$ of the variations in the long run respectively. The variance decomposition of the IMP shows that among all the variables, its own shock does dominate in explaining its variability accounting to the tune of $99 \%$ to $89 \%$ of its changes. Other sources of the variability in IMP are GEXP and RGDP account up to $6 \%$ and $2 \%$ of the forecast error variance during the period under review. The result from the table also shows that OILPVOL could not explain much of the variability in IMP, accounting about just $1.1 \%$ in the long run.

Table 11: Variance Decomposition of IMP

\begin{tabular}{lllllllll}
\hline Period & S.E. & OILPVOL & RGDP & IR & INF & IMP & GEXP & EXR \\
\hline $\mathbf{1}$ & 136989.4 & 0.000000 & 0.013707 & 0.028286 & 0.001549 & 99.78184 & 0.167388 & 0.007228 \\
$\mathbf{2}$ & 185348.9 & 0.532277 & 1.105323 & 0.033796 & 0.011605 & 97.73049 & 0.562174 & 0.024333 \\
$\mathbf{3}$ & 222491.6 & 0.978194 & 1.460384 & 0.119644 & 0.016529 & 96.45404 & 0.943464 & 0.027741 \\
$\mathbf{4}$ & 257278.9 & 1.116036 & 1.499595 & 0.301326 & 0.020377 & 95.56544 & 1.467802 & 0.029427 \\
$\mathbf{5}$ & 292027.2 & 1.148647 & 1.478465 & 0.512015 & 0.024613 & 94.61225 & 2.193235 & 0.030778 \\
$\mathbf{6}$ & 327414.7 & 1.147861 & 1.499137 & 0.705409 & 0.030777 & 93.58647 & 2.997325 & 0.033021 \\
$\mathbf{7}$ & 363358.4 & 1.138109 & 1.596675 & 0.867996 & 0.039668 & 92.49360 & 3.827106 & 0.036850 \\
$\mathbf{8}$ & 399697.9 & 1.126642 & 1.775677 & 1.000045 & 0.051054 & 91.36235 & 4.641693 & 0.042541 \\
$\mathbf{9}$ & 436356.1 & 1.115756 & 2.026003 & 1.106026 & 0.063759 & 90.22089 & 5.417583 & 0.049986 \\
$\mathbf{1 0}$ & 473325.5 & 1.105603 & 2.332309 & 1.190923 & 0.076184 & 89.09273 & 6.143343 & 0.058911 \\
\hline
\end{tabular}

Authors' Computation 


\section{Conclusion and Policy Implications}

In conclusion, the data analysis in this work started with the descriptive statistics result, which indicates that all the variables under consideration have positive mean with 140 observations. The highest standard deviation was recorded by Government Expenditure of 1651571 while the least standard deviation of 2.878867 is recorded by Interest Rate. We therefore conclude that since the Jarque-Bera probability for the variables shows that the error terms are normally distributed, and then the regression result is good. To test for stationarity or the absence of unit roots was carried out using the Augmented Dickey Fuller test (ADF) and Philip Perron which gave almost the same result that all the variables are integrated of order one I(1) except inflation rate and import under the ADF test which were stationary at level, hence the variables does not have a unit test.

The Correlation result shows that apart from inflation which reveals a negative relationship with OILPVOL all the other variables have positive and strong relationship with OILPVOL. The negative relationship between OILPVOL and INF depicts that with a rise in OILPVOL, INF will come down while a positive relationship of OILPVOL with RGDP, (EXR), (GEXP), (IMP), and (IR) implies that they are directly related. The causality test that was conducted reveals a bi-directional causality running between OILPVOL and RGDP, hence, an increase in income will likely lead to more of this risen income being shift to other economies in form of excess purchase of crude oil final product leading to capital flight which in turn bring about a fall in Naira exchange rate which (all things being equal) has the capacity of attracting capital back into the economy and then a vicious circle can be ensued. The causality test also reveals there is a unidirectional causality running from Oil Price Volatility to Money Supply, Exchange rate to Oil Price Volatility and Government Expenditure to Oil Price Volatility which was consistent with the findings of Apere and Ijomah (2013) in Nigeria that there is a unidirectional relationship exists between exchange rate and oil prices, and a significant relationship between oil prices and real GDP was not found. Though there were no causal relationship between Oil Price Volatility, interest rate and Inflation rate as presented in this work but Apere and Ijomah (2013)were of the view that there is. Moreover, the multiple regression analysis reveals that OILPVOL does actually impact on the Nigerian economy because the probability test is less than $5 \%$ and if OILPVOL increases by one unit, RGDP will increase by 525.5 units.

In addition, the dynamic properties of the VAR Model were interpreted using the impulse response function and variance decomposition. The response of RGDP, IR, GEXP and EXR to one standard deviation in OILPVOL all shows a positive response and stabilizes along the horizon in the long run. Whereas the impulse response of the IMP and INF to one standard innovation in the OILPVOL is negative and stable in the short run but rises along the horizon and becomes positive in the long run. Finally, the impulse response of IR to one standard deviation in OILPVOL is positive but fluctuates into negative along the horizon in the long run. Its variance decomposition shows that among all the variables, its own shock explains about $76 \%$ to $53 \%$ of the forecast error variance during the period under review; while OILPVOL explain about $4 \%$ of the changes in the IR. INF responds negatively to one standard innovation in OILPVOL both in the short and long run. The result of the variance decomposition of INF shows that OILPVOL does not show any pattern of impact on the forecast error of INF both in the short and long run. A response of GEXP to OILPVOL shock indicates a positive and OILPVOL account for the forecast error variance in GEXP ranging from $0 \%$ to $16 \%$. The impulse response function of the EXR to one standard innovation in OILPVOL shock indicates a positive but fluctuates along the horizon in the long run negatively while its variance decomposition from one standard innovation in OILPVOL average $1.6 \%$ in the short run to $15 \%$ in the long run.

Policy Implication: A lot of policy implications can be deduced from the findings made in this work. Information gathered from this study reveals that oil price volatility stimulate Nigeria's real gross domestic product through government expenditure because it could explain the variability in this variables both in the short and long run and the short run causality was further strengthened by the granger causality test revealing a bi-causality. This implies that a good fiscal policy measure could stimulate both internal and external balances. Therefore government expenditure changes with changes in oil generated revenue. This finding is consistent with other empirical evidence such as corroborate findings by (Rolle \& Uffie, 2015) and Richard and Ronald (1980).Moreover, the impulse response of Interest Rate (IR) to one standard deviation in OILPVOL is negative and fluctuates further into negative both in the short and long run. This result simply 
suggests that a steady fluctuating oil prices will necessitate an expansionary monetary policy measure which will further generate internal imbalances. This is because, with a fall in interest rate, aggregate expenditure will exceed potential output; therefore, the excess will be supplemented from output from abroad which can give rise to further external imbalance. Moreover, this can further deteriorate the exchange rate and other macroeconomic variables. Therefore the combination of a monetary and fiscal policy measures will be necessary to restore the economy back to equilibrium.

Furthermore, INF responds negatively to one standard innovation in OILPVOL both in the short and long run and the result of the variance decomposition of INF shows that OILPVOL does not show any pattern of impact on the forecast error of INF both in the short and long run. The correlation matrix and the variance decomposition of inflation further amplify this with a negative and a low relationship and no variability in inflation was explained by oil price volatility respectively. This therefore suggests that domestic inflation could not be explained by the fluctuations in the oil price. Hence, the Nigerian inflation rate could be as a result of structural changes, increase in money supply and consumers' expectation of high inflation rate. However, Oriakhi and Iyoha (2013) opined that oil price volatility only impacts on broad money supply when crude oil sales proceeds are monetized, thereby bringing to light the possibility of oil price volatility leading to inflation by increasing the Money supply.

Recommendation: Based on the findings from my study, the following recommendations are therefore made:

- The Federal Government need to diversify the economy to other sectors of the economy rather than concentrate only on the oil sector as the only source of revenue to the country.

- The Federal Government through the Central Bank are advised to simultaneously pursue an expansionary monetary and expansionary fiscal policies during periods of high volatility in Oil Price (in this case; a persistent increase) so as to be able to still maintain a stable equilibrium in the economy and vice versa.

- Government should ensure the adoption of an effective monetary policy measure as it does help in maintaining both internal and external balance under a floating exchange rate system.

- Attention should be given to other factors or determinants of income in Nigeria as it has a bidirectional causality with Oil Price Volatility.

- Investors are therefore encouraged to fully participate in the economy as it will help to generate foreign reserves for the economy.

\section{References}

Abraham, W. T. (2015). Exchange Rate Policy and Falling Crude oil Prices: Effect on the Nigerian Stock Market. CBN Journal of Applied Statistics, 7(1).

Ahuru, R. R.\& James, U. E. (2015). Macroeconomics of Oil Price Volatility.

AL-Ezzee, I. (2011). Real influences of Real Exchange rate and Oil price changes on the growth of real GDP. International Conference of Management and service science.Bahrain.

Aliyu, U. R. (2009). Impact of oil price stock and exchange rate volatility on economic growth in Nigeria: An emperical investigation. Research journal of international studies, 3, 4-15.

Apere, 0. T. \& Ijomah A. M. (2013). Macroeconomic Impact of Oil Price Levels and Volatility in Nigeria. International Journal of Academic Research in Economics and Management Sciences, 2(4), 2226-3624. URL: http://dx.doi.org/10.6007/IJAREMS/v2-i4/48

Blanchard, 0.\& Gali, J. (2008). The Macroeconomic Effect of Oil Price Shocks: Why are the 2000s so different from the 1970s? NBER, International Dimensions of Monetary Policy.

Carruth, A. A., Hooker, M. A.\& Oswald, A. J. (1996). Unemployment Equilibria and Input Prices: Theory and Evidence for the United States. Review of Economics and Statistics.

Cashin, P., Liang, H. \& Mcdermoth, C. J. (2000). How persistent are shocks to world Commodity price ? MF Staff Papers, vol.47.

CBN. (2012). Central Bank of Nigerian's Statistical Bulletin for 2012.

CBN. (2015). Central Bank of Nigerian's Statistical Bulletin for 2015.

Chen, S. S.\& Chen, H. C. (2007). Oil prices and real exchange rate. Energy Economics,29, 390-404. 
Daniel , N. C. (1997). International Interdependence of National Growth Rates: A structural Trends Analysis. Journal of Monetary Economics, 3, 73-96.

Englama, A., Duke, O. O., Ogunleye, S. \& Isma F. U. (2010). Oil Price and Exchange rate Volatility in Nigeria: An Empirical observation.

Granger, C. W. J. (1969). Prediction with a generalized cost of error function. Operational Research Quarterly, 20, 199-207

Habib, M. M.\& Kalamova, M. (2007). Are There Oil Currencies? The Real Exchange Rate of Oil Exporting Countries, In European Central Bank working Paper.

Hamilton, J. D. (1983). Oil and the Macroeconomy since World War II. Journal of Political economy,91, 228-48.

Hassan, S.\& Zahid, M. (2011). The real exchange rate of exporting economy: EmpiricaL evidence from Nigeria, FIW working paper 72 , September.

Hodo, B., Akpan, E.\& Offiong, A. (2013). Asymmetric effect of oil price shocks on exchanges rate volatility and domestic investment in Nigeria. British Journal of Economics, Management and Trades, 3(4), 513-532.

Hooker, M. A. (1996). What Happened to the Oil Price Macroeconomy Relationship? Journal of Monetary Economics, 38,195-213.

Katsuya, I. (2010). The Impact of Oil Price Volatility on Macroeconomic Activity in Russia . Economic Analysis Working Papers, 9(5).

Kim, I. M. \& Loughani, P. (1992). The Role of Energy in Teal Business Cycles. Journal of Monetary Economics, 2, 173-189.

Majidi, M. (2006). Impact of Oil on International Economics Course. Centre for Science and Innovation Studies.

Masih, R., Peter, S.\& Mello, L. (2010). Oil Price Volatility and Stock Price Fluctuations in an Emerging Market: Evidence from South Korea, 1-32.

Mork, K. A. (1994). Business Cycles and the Oil Market. Energy Journal,15, 15- 38.

Obadan, M. I. (2014). Nigeria at 50 and its national economic development paradigms: The benefit of hind sight. A lecture delivered at the occasion of Nigeria's 50th Independence Anniversary at the Auchi Polytechnic, Auchi.

Obioma, R. (2006). An examination of oil prices and its changes on the Nigerian Economic Growth. J. Welfare Econ., 4(2), 25-28.

Ogundipe, M. O., Ojeagaa, P.\& Ogundipe, A. A. (2014). Oil Price and Exchange Rate Volatility in Nigeria. Journal of Economics and Finance, 5(4), 2321-5925.

Olomola, P. (2006). Oil Price shocks and aggregate economic activity in Nigeria. African Economic and Business Review, 4(2), 40-45.

Oriakhi, D. E.\& Osaze, D. (2010). Oil Price Volatility and Its Consequences On the Growth of the Nigerian Economy: An Examination (1970- 2010). Asian Econ. Finan., 5(3), 683-702.

Oriakhi, D. E. \&Iyoha, D. O. (2013). Oil Price volatility and Its consequences on the growth of the Nigeria's economy: an examination (1970-2010).Asian Economic and Financial Review, 3(5), 683-702.

Philip, A. 0.\& Akintoye, V. A. (2006). Oil Price shock and Macro-economic activities in Nigeria. International Research Journal of Finance and Economics,3(2).

Rolle, R. A.\& Uffie, E. J. (2015). Macroeconomics of Oil Price Volatility. ISSN 15968303.www.transcampus.org/journal; www.ajol.info/journals/jorind

Runkle D. E.(1987). Vector Autoregressions and Reality. Journal of Business and Economic Statistics, 5(4), 437442.

Sims, C. (1987). Bayesian Skepticism on Unit Root Econometrics. Journal of Economic Dynamics and Control, $12,463-474$.

Tatom, J. (1988). Are the macroeconomic effects of oil price changes symmetric? Carnegie Rochester Conference Series on Public Policy, 28,325-368.

Verheyen, F.(2010). Monetary Policy, Commodity Prices and Inflation - Empirical Evidence from the US, RUHR Economic papers

Wilson, A., Ugwunta , D., Oliver , I.\& Eneje, B. (2014). Oil price volatility and economic development: Stylized evidence in Nigeria. Journal of Economics and International Finance, 6(6), 125-133. 